\title{
A case report of complement $C 4 B$ deficiency in a patient with steroid and IVIG-refractory anti-NMDA receptor encephalitis
}

\author{
Gilbert T. Chua', Danlei Zhou' ${ }^{2}$, Alvin Chi Chung Ho ${ }^{1}$, Sophelia Hoi Shan Chan ${ }^{1}$, Chack Yung Yu ${ }^{2}$ and
} Yu Lung Lau ${ }^{1 *}$ (D)

\begin{abstract}
Background: Complement C4A or C4B deficiency has never been reported in autoantibody-associated encephalitides patient. Here we present a case of anti-N-methyl- D-aspartate (NMDA) receptor encephalitis associated with homozygous C4B deficiency, who did not respond to intravenous immunoglobulin and pulse methylprednisolone but plasmapheresis and rituximab.

Case presentation: A fourteen-year-old boy presented to our unit with subacute onset of behavioral changes and confusion, and was later confirmed to be anti-NMDA receptor encephalitis. He was initially managed with intravenous immunoglobulin (IVIG) and pulse methylprednisolone but did not achieve any clinical improvement. Seven sessions of plasmapheresis was commenced with remarkable improvement after the second session, and was followed by four doses of rituximab. His neurological and cognitive functioning gradually returned to baseline. Immunological investigations demonstrated persistently low C4 levels below $8 \mathrm{mg} / \mathrm{dL}$. A more in-depth complement analysis of the patient and his family showed that he has homozygous C4B deficiency. Genetic analysis revealed that the index patient has homozygous deficiency in complement $C 4 B$ and he carries one nonfunctioning mutant $C 4 B$ gene inherited from his mother.

Conclusions: Low levels of serum C4 correlate with reduced functions of the classical and lectin pathways, leading to the impairment of immune-complexes removal. Plasmapheresis ameliorates complement deficiency and removes the offending immune-complexes leading to clinical improvement that was not achieved by IVIG and steroids. We postulate that serum C4 levels may serve as a biomarker for the need of plasmapheresis upfront rather than only after non-response to steroid and IVIG in treating anti-NMDA-receptor encephalitis.
\end{abstract}

Keywords: Anti-NMDA receptor encephalitis, Homozygous C4B deficiency, Plasmapheresis

\footnotetext{
* Correspondence: lauylung@hku.hk

'Department of Paediatrics and Adolescent Medicine, Queen Mary Hospital,

The University of Hong Kong, Room 106, 1/F, New Clinical Building, 102

Pokfulam Road, Pokfulam, Hong Kong

Full list of author information is available at the end of the article
}

(c) The Author(s). 2020 Open Access This article is licensed under a Creative Commons Attribution 4.0 International License, which permits use, sharing, adaptation, distribution and reproduction in any medium or format, as long as you give appropriate credit to the original author(s) and the source, provide a link to the Creative Commons licence, and indicate if changes were made. The images or other third party material in this article are included in the article's Creative Commons licence, unless indicated otherwise in a credit line to the material. If material is not included in the article's Creative Commons licence and your intended use is not permitted by statutory regulation or exceeds the permitted use, you will need to obtain permission directly from the copyright holder. To view a copy of this licence, visit http://creativecommons.org/licenses/by/4.0/. The Creative Commons Public Domain Dedication waiver (http://creativecommons.org/publicdomain/zero/1.0/) applies to the data made available in this article, unless otherwise stated in a credit line to the data. 


\section{Background}

Complement $\mathrm{C} 4$ plays a crucial role in the activation of the classical and lectin complement pathways. It has two isotypes, $\mathrm{C} 4 \mathrm{~A}$ and $\mathrm{C} 4 \mathrm{~B}$. While deficiency of $\mathrm{C} 4 \mathrm{~A}$ and $\mathrm{C} 4 \mathrm{~B}$ are detectable at low frequency in healthy populations, they have also been reported to be associated with various autoimmune and inflammatory diseases $[1,2]$. However, a $\mathrm{C} 4 \mathrm{~A}$ or $\mathrm{C} 4 \mathrm{~B}$ deficiency has never been reported in autoantibody-associated encephalitides patient. Here we report a case of anti- $N$-methyl- D-aspartate (NMDA) receptor encephalitis associated with homozygous $\mathrm{C} 4 \mathrm{~B}$ deficiency.

\section{Case presentation}

Our patient is a fourteen-year-old boy with background of mild attention-deficit and hyperactive disorder. $\mathrm{He}$ has insignificant family history of neurological, psychological or immunological disorders. Preceded by two weeks of viral illness-like prodromal symptoms, he progressively developed hypersomnolence, confused speech with echolalia, self-muttering, dysarthria, mood fluctuation, bilateral upper limbs tremor, and headache. Physical examination was unremarkable, apart from having confusion, inappropriate speech with foul languages, urine and fecal incontinence. Investigations showed normal complete blood count, liver and renal function tests. Autoimmune markers including anti-nuclear antibodies and anti-double stranded DNA antibody were negative. His serum C3 levels were within normal range between 109 and $115 \mathrm{mg} / \mathrm{dL}$, but his C4 levels were persistently below $8 \mathrm{mg} / \mathrm{dL}$ (Table 1). MRI brain was normal. Electroencephalogram showed a mild slowing of background activities. Cerebrospinal fluid (CSF) analysis demonstrated a total white cell count of 33 cells $/ \mathrm{mm}^{2}$, with normal protein and glucose levels. Oligoclonal protein was detected in the CSF. Microbiological investigations including bacterial cultures and viral polymerase chain reactions for herpes simplex virus, varicella zoster virus and enteroviruses were all negative. Anti-NMDA receptor antibodies based on commercial assay
(Euroimmune ${ }^{\oplus}$, Lueback, Germany) were detectable (titer $<1: 10$ ) in the CSF but not the serum.

The diagnosis of anti-NMDA receptor encephalitis was made based on the diagnostic criteria published by Graus et al. [3] He was immediately given intravenous immunoglobulin (IVIG) $1 \mathrm{~g} / \mathrm{kg}$ for on day 2 of admission for two consecutive days followed by pulse methylprednisolone 1 g on day 6 of admission for five days with gradual taper. However, he did not demonstrate any clinical improvement after IVIG and pulse methylprednisolone.

Plasmapheresis was therefore performed for a total of 7 sessions between day 14 and 29 of admission, with sedation required for the initial two sessions. He demonstrated significant improvement after the second session and was able to complete the remaining plasmapheresis without sedations. Nevertheless, his cognitive improvement remained slow and four doses of rituximab at 375 $\mathrm{mg} / \mathrm{m}^{2} /$ dose at weekly intervals were given between day 35 and 56 of admission. Accelerated improvement was observed after the second dose in terms his self-care abilities, behavior and cognitive functions. He was discharged after eight weeks of admission with some residual cognitive impairment requiring rehabilitation.

In view of his low C4 protein levels, an in-depth genetic analysis of the index patient, his parents and his maternal stepbrother was performed (Fig. 1; Table 1, Supplementary Fig. 1). Long-range mapping by pulsed field gel electrophoresis of PmeI-digested genomic DNA revealed heterozygosity with bimodular (LL) and monomodular (L) RP-C4-CYP21-TNX (RCCX) haplotypes (panel A). Regular Southern blots of TaqI digested genomic DNA revealed the presence of three long $C 4$ genes in $\mathrm{LL} / \mathrm{L}$ configurations (panel $\mathrm{B}$ ), by which two $C 4$ genes belong to the $C 4 A$ isotype and one $C 4$ gene belongs to the $C 4 B$ isotype, as shown by PshAI/PvuII Southern blot (panel C). Immunofixation experiment of EDTA-plasma showed that the patient expressed C4A protein but no $\mathrm{C} 4 \mathrm{~B}$ protein (panel D) [4]. In other words, the patient contained a $C 4 B$ gene that did not produce a $C 4 B$ protein (panels $\mathrm{C}$ and $\mathrm{D}$, arrows) and thus assigned a $C 4 B$

Table 1 Complement genetic profiles of the patient and his family members

\begin{tabular}{|c|c|c|c|c|c|c|c|c|c|c|c|c|}
\hline & $\begin{array}{l}\text { Plasma C4 } \\
(\mathrm{mg} / \mathrm{dL})\end{array}$ & $\begin{array}{l}\text { Plasma C3 } \\
(\mathrm{mg} / \mathrm{dL})\end{array}$ & $\begin{array}{l}\text { RCCX-C4 } \\
\text { haplotypes }\end{array}$ & $\begin{array}{l}\text { Total } \\
\text { C4 GCN }\end{array}$ & $\begin{array}{l}\text { C4 } \\
\text { Long } \\
\text { GCN }\end{array}$ & $\begin{array}{l}\text { C4 } \\
\text { Short } \\
\text { GCN }\end{array}$ & $\begin{array}{l}\text { C4A } \\
\text { GCN }\end{array}$ & $\begin{array}{l}\mathrm{C} 4 \mathrm{~B} \\
\mathrm{GCN}\end{array}$ & $\begin{array}{l}\text { C4A } \\
\text { Protein }\end{array}$ & $\begin{array}{l}\text { C4B } \\
\text { Protein }\end{array}$ & $\begin{array}{l}\text { C4 protein } \\
\text { Haplotype1 }\end{array}$ & $\begin{array}{l}\text { C4 protein } \\
\text { Haplotype2 }\end{array}$ \\
\hline Patient & 7.7 & 118.5 & $\mathrm{LL} / \mathrm{L}$ & 3 & 3 & 0 & 2 & (1) & $\mathrm{A} 3 \mathrm{~A} 3$ & $\mathrm{Q}_{0}$ & $\mathrm{~A} 3 \mathrm{Q}_{0}$ & A3 \\
\hline Mother & 20.2 & 106.4 & LL / LLS & 5 & 4 & 1 & 3 & $2(1)$ & $\mathrm{A} 3 \mathrm{~A} 3 \mathrm{~A} 3$ & $B 2, Q_{0}$ & $\mathrm{~A} 3 \mathrm{Q}_{0}$ & A3A3B2 \\
\hline Father & 19.2 & 167.6 & $L / L$ & 2 & 2 & 0 & 2 & 0 & A3A3 & & A3 & A3 \\
\hline $\begin{array}{l}\text { Maternal } \\
\text { Step Brother }\end{array}$ & 10.0 & 91.1 & $\mathrm{LL} / \mathrm{L}$ & 3 & 3 & 0 & 1 & $2(1)$ & $\mathrm{A} 3$ & $\mathrm{~B} 1, \mathrm{Q}_{0}$ & $\mathrm{~A} 3 \mathrm{Q}_{0}$ & B1 \\
\hline
\end{tabular}

GCN gene copy number, $L$ C4 long gene, S C4 short gene, LL long-long, LS long-short, LLS long-long-shortm, $A 3$ C4A allotype 3 


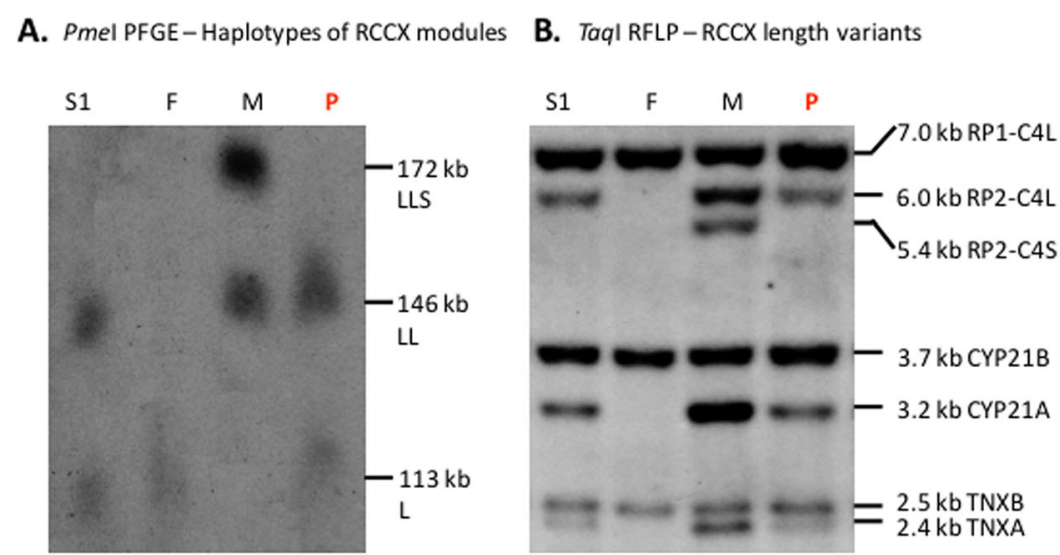

C. PshAI-Pvull RFLP-C4A and C4Bgenes

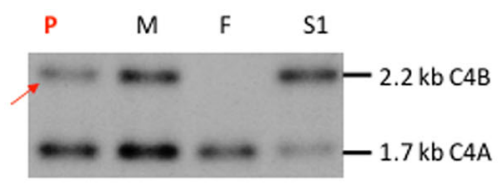

D. Immunofixation of $\mathrm{C} 4$ protein

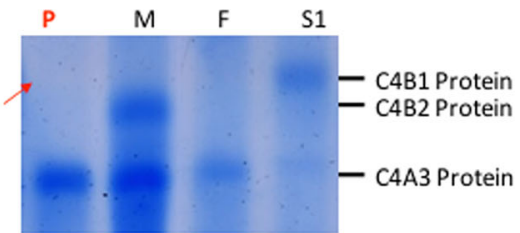

Fig. 1 Molecular genetic characterization of the encephalitis patient withantibodies against NMDA-receptor and his family members. a. Pulsed field gel electrophoresis (PFGE) of Pmel digested genomic DNA to show RP-C4-CYP21-TNX (RCCX) haplotypes; $\mathbf{b}$. Taql restriction fragment polymorphism (RFLP) to show details of RCCX structures with long (L) and short (S) C4 genes; c. PshAI/Pvull RFLP to show the presence and ratios of C4B and C4A genes; $\mathbf{d}$. Immunofixation of EDTA-plasma to show polymorphisms of C4A and C4B proteins. A red arrow showed the presence of a C4B gene in panel C but no C4B protein in panel D. Data interpretation is tabulated in Table 1. Abbreviations: P, patient; F, father; M, mother; S1, stepbrother.

mutant. Concurrent study of the patient's parents and maternal stepbrother suggested the patient (Fig. 1, Table 1) inherited the mutant $C 4 B$ gene originated from their mother with a LL haplotype consisting of one long $C 4 A$ gene coding for $C 4 A 3$ protein, and one long mutant $C 4 B$ gene with no product.

\section{Discussion and conclusions}

Deficiency of $\mathrm{C} 4 \mathrm{~B}$ proteins, low gene copy number or mutation of $C 4 B$ gene has not been reported in any autoimmune encephalitides. Therefore, its potential role in the development of anti-NMDA receptor encephalitis remains to be established. Classical pathway complement proteins such as $\mathrm{C} 1 \mathrm{q}$ and $\mathrm{C} 4$ have been implicated in the wiring of neurons, or the formation and pruning of synapses in the brain [5]. High copy number of $C 4 A$, which can also be presented as low copy number of $C 4 B$ because a $C 4$ gene either codes for $C 4 A$ or $C 4 B$ protein [2], are associated with schizophrenia [6].

Low levels of serum $\mathrm{C} 4$ correlate with reduced functions of the classical and lectin pathways, leading to the impairment of immune-complexes removal [7]. Our patient was a poor responder to IVIG and pulse glucocorticoids but achieved significant improvement after plasmapheresis and rituximab. While a study by Martinez-Hernandez et al. demonstrated that complement-mediated cytotoxicity, i.e. cellular destruction through deposition of $\mathrm{C} 3 \mathrm{~b}$ and formation of membrane attack complexes C5b-9, was not readily detectable in the pathogenesis of anti-NMDA receptor encephalitis, their study did not examine the activation of early classical pathway complement components such as $\mathrm{C} 1 \mathrm{q}$ and $\mathrm{C4}$ [8]. This would be relevant because complement activation on autologous cells are tightly controlled and mostly stop after the deposition of C4b. We postulate that $\mathrm{C} 4 \mathrm{~B}$ deficiency in our patient might have led to the defective removal of immune complexes and possibly impairment of yet to be characterized neurogenic pathways, which has a substantial role in autoimmune encephalitis [9-11]. Complement deficiency is ameliorated by plasmapheresis, which normally correct the complement deficiency, but not by IVIG. Plasmapheresis also effectively removes offending autoantibodies and immune-complexes [12]. The use of rituximab, an anti-CD20 monoclonal antibodies, depletes $\mathrm{CD}_{20}{ }^{+} \mathrm{B}$ cells, preventing further autoantibody production and immune complex formation [8]. These strategies lead to a sustained clinical improvement. It remains to be determined if routine plasmapheresis is required to keep patient's disease in remission.

Further studies investigating the complement profiles and circulating immune complexes in patients with antiNMDA receptor and other autoimmune encephalitides would clarify the role of $C 4 B$ deficiency. A study by Shu et al. demonstrated that southern Chinese patients with anti-NMDA receptor encephalitis had higher C4 levels among female patients $(N=19)$ than female healthy controls $(N=16)$, the sample sizes (for controls) were relatively small and required validation. Moreover, genetic deficiency of C4B was not examined [13]. While the best first-line therapeutic option (steroid, IVIG or plasmapheresis) to treat anti-NMDA receptor encephalitis remains debatable [14], inheritently low C4 levels or C4B deficiency may be a biomarker for the need of plasmapheresis upfront rather than only after non-response to steroid and IVIG. 


\section{Supplementary information}

Supplementary information accompanies this paper at https://doi.org/10. 1186/s12883-020-01906-x.

\section{Additional file 1.}

\section{Abbreviations}

A3: C4A allotype 3; B1: C4B allotype 1; B2: C4B allotype 2; CSF: Cerebrospinal fluid; GCN: Gene copy number; IVIG: Intravenous immunoglobulin; NMDA: Anti-N-methyl-D-aspartate; L: C4 long gene; LL: Long-long; LS: Longshort; LLS: Long-long-short; S - C4: Short gene.; PFGE: Pulsed field gel electrophoresis; $Q_{0}$ : Zero quantity of $C 4$ protein from the corresponding gene; RFLP: Restriction fragment polymorphism

\section{Acknowledgements}

We thank the patient and his family members for support of this study. We are indebted to Ms. Bi Zhou for technical assistance.

\section{Authors' contributions}

GTC, YLL, ACCH, SHSC made the diagnosis and performed clinical studies of the patient. DZ and CYY performed complement studies. GTC, YLL, DZ and CYY wrote the manuscript draft. All authors approved the final version of the manuscript.

\section{Funding}

This work was partially supported by National Institutes of Health grant R01 AR073311 from the National Institute of Arthritis, Musculoskeletal and Skin Diseases (CYY), and a donation from the Hong Kong Society for the Relief of Disabled Children (YLL). Both funding were not involved in the design of the study and collection, analysis, and interpretation of data and in writing the manuscript.

\section{Availability of data and materials}

The laboratory data for this study were shown in Table 1 and Fig. 1. Further clinical data would be available from the corresponding author on reasonable request.

\section{Ethics approval and consent to participate}

This study was performed after approved IRB protocol (ID\# MOD00003296) entitled "The Major Histocompatibility Complex (MHC) and Gene Copy Number Variations (CNVs) in Human Disease Associations" from The Nationwide Children's Hospital. All of the family members involved in this study signed informed consents to participate.

\section{Consent for publication}

Written consent for publication is obtained from the parents of index patient, with ascent obtained from the patient. The patient and first-degree relatives were deidentified.

\section{Competing interests}

The authors declare that they have no competing interests.

\section{Author details}

${ }^{1}$ Department of Paediatrics and Adolescent Medicine, Queen Mary Hospital, The University of Hong Kong, Room 106, 1/F, New Clinical Building, 102 Pokfulam Road, Pokfulam, Hong Kong. ${ }^{2}$ Center for Microbial Pathogenesis and Division of Rheumatology, Abigail Wexner Research Institute at Nationwide Children's Hospital and Department of Pediatrics, The Ohio State University, 700 Children's Drive, Columbus, OH 43205, USA

\section{Received: 13 November 2019 Accepted: 23 August 2020}

Published online: 08 September 2020

\section{References}

1. Chen JY, Wu YL, Mok MY, et al. Effects of complement C4 gene copy number variations, size dichotomy, and C4A deficiency on genetic risk and clinical presentation of systemic lupus Erythematosus in east Asian populations. Arthritis Rheumatol. 2016;68(6):1442-53.
2. Lintner KE, Wu YL, Yang Y, et al. Early components of the complement classical activation pathway in human systemic autoimmune diseases. Front Immunol. 2016;7:36

3. Graus F, Titulaer MJ, Balu R, et al. A clinical approach to diagnosis of autoimmune encephalitis. Lancet Neurol. 2016;15(4):391-404.

4. Chung EK, Wu YL, Yang Y, Zhou B, Yu CY. Human complement components C4A and C4B genetic diversities: complex genotypes and phenotypes. Curr Protoc Immunol. 2005; Chapter 13:Unit 13.18.

5. Johnson MB, Stevens B. Pruning hypothesis comes of age. Nature. 2018, 554(7693):438-9.

6. Sekar A, Bialas AR, de Rivera $H$, et al. Schizophrenia risk from complex variation of complement component 4. Nature. 2016;530(7589):177-83.

7. Yang $Y$, Chung EK, Zhou B, et al. Diversity in intrinsic strengths of the human complement system: serum C4 protein concentrations correlate with C4 gene size and polygenic variations, hemolytic activities, and body mass index. J Immunol. 2003;171(5):2734-45.

8. Martinez-Hernandez E, Horvath J, Shiloh-Malawsky Y, Sangha N, MartinezLage M, Dalmau J. Analysis of complement and plasma cells in the brain of patients with anti-NMDAR encephalitis. Neurology. 2011;77(6):589-93.

9. Bien CG, Vincent A, Barnett MH, et al. Immunopathology of autoantibodyassociated encephalitides: clues for pathogenesis. Brain. 2012;135(Pt 5): 1622-38.

10. Qiu X, Zhang H, Li D, et al. Analysis of Clinical Characteristics and Poor Prognostic Predictors in Patients With an Initial Diagnosis of Autoimmune Encephalitis. Front Immunol. 2019;10(1286).

11. Magdalon J, Mansur F, Teles E Silva AL, de Goes VA, Reiner O, Sertié AL. Complement system in brain architecture and neurodevelopmental disorders. Front Neurosci 2020;14:23-23.

12. Schwartz J, Padmanabhan A, Aqui N, et al. Guidelines on the use of therapeutic apheresis in clinical practice-evidence-based approach from the writing Committee of the American Society for apheresis: the seventh special issue. J Clin Apher. 2016;31(3):149-62.

13. Shu $Y$, Chen $C$, Chen $Y$, et al. Serum complement levels in anti-N-methyl-daspartate receptor encephalitis. Eur J Neurol. 2018;25(1):178-84.

14. Shin Y-W, Lee S-T, Park K-I, et al. Treatment strategies for autoimmune encephalitis. Ther Adv Neurol Disord 2017;11:17562856177223471756285617722347

\section{Publisher's Note}

Springer Nature remains neutral with regard to jurisdictional claims in published maps and institutional affiliations.

Ready to submit your research? Choose BMC and benefit from:

- fast, convenient online submission

- thorough peer review by experienced researchers in your field

- rapid publication on acceptance

- support for research data, including large and complex data types

- gold Open Access which fosters wider collaboration and increased citations

- maximum visibility for your research: over $100 \mathrm{M}$ website views per year

At $\mathrm{BMC}$, research is always in progress.

Learn more biomedcentral.com/submission 